\title{
Investigation on Coal Slagging Characteristics and Combustion Behaviour in Furnace
}

\author{
Nor Jauhara Sophia ${ }^{1}$ and Hasril Hasini ${ }^{1, a}$ \\ ${ }^{1}$ Fluid Dynamics and Risk Reduction Research Group, Institute of Sustainable Engineering, Universiti Tenaga \\ Nasional, Jalan IKRAM-UNITEN, 43000 Kajang, Malaysia
}

\begin{abstract}
This paper describes an investigation of coal characteristics and slagging potential using coal slagging assessment tool such as numerical slagging indices. Historical data on coal use according to type and shipment in power plant was use for the analysis. It is found that higher content of silica oxide results in higher softening temperature and the monomers modifiers can alter the softening temperature. Calculation also reveals encouraging conditions that could possibly prevent the slagging potential inside the furnace.
\end{abstract}

\section{Introduction}

Slagging in the furnace poses problem to coal power station at it reduce the efficiency of heat transfer to water in water tubes. The right viscosity of coal at high temperature has to be in the correct range to ensure good combustion performance of the coals. The ash analysis coals slagging numerical indices has been studied, tested and integrated with actual plant data to obtain numerical slagging indices [16]. The importance of the slagging numerical indices is to segregate and classify the coals based on its ash analysis and predict its tendency to change physical properties to slag. In this work, attempt was made to analyse and rank the coals of several type, brand and rank of coals. Coals are ranked to subbituminous or bituminous based on its carbon content. This study focused on the types of coals commonly used in one of the biggest power plant in Malaysia. Recent operational problem has shown that large chunk of coal slag was formed and subsequently fall to the bottom hopper of the boiler, causing significant damage to the furnace. Hence, analysis of the formation of slagging using historical operational data is carried out to establish the understanding in terms of ash analysis and tendency to slag, by taking into account the temperature correlation between the viscosity, mineral components and either guiding parameters.

\section{Materials and methods}

\subsection{Numerical Slagging Indices}

The coals quality database was obtained from plant historical operation data. The database includes crucial data for coal certificate of ultimate analysis and proximate ash analysis. The useful data were

\footnotetext{
${ }^{\mathrm{a}}$ Corresponding author: hasril@uniten.edu.my
} 
Table 1 Summary of some existing slagging indices [1-6]

\begin{tabular}{|c|c|c|c|c|c|c|}
\hline \multirow[t]{2}{*}{ Author (s) } & \multirow[t]{2}{*}{ Basis } & \multirow{2}{*}{ Slagging Indices } & \multicolumn{4}{|c|}{ Slagging potential } \\
\hline & & & low & Medium & High & Severe \\
\hline $\begin{array}{l}\text { Lawrence et al. } \\
2008\end{array}$ & $\begin{array}{l}\text { Silica } \\
\text { Ratio }\end{array}$ & $\begin{aligned} \mathrm{SR}=100\left(\mathrm{SiO}_{2} / \mathrm{SiO}_{2}\right. & +\mathrm{Fe}_{2} \mathrm{O}_{3}+\mathrm{CaO} \\
& +\mathrm{MgO}\end{aligned}$ & $72-80$ & $65-72$ & $50-65$ & - \\
\hline $\begin{array}{l}\text { Lawrence et al. } \\
2008\end{array}$ & B/A Ratio & $\begin{array}{l}\mathrm{B} / \mathrm{A} \\
=\frac{\mathrm{Fe}_{2} \mathrm{O}_{3}+\mathrm{CaO}+\mathrm{MgO}+\mathrm{K}_{2} \mathrm{O}-\mathrm{Na}_{2} \mathrm{O}}{\mathrm{SiO}_{2}+\mathrm{Al}_{2} \mathrm{O}_{3}+\mathrm{TiO}_{2}}\end{array}$ & $<0.11$ & $\begin{array}{l}0.11- \\
0.14\end{array}$ & $>0.14$ & - \\
\hline $\begin{array}{l}\text { Lawrence et al. } \\
2008\end{array}$ & $\begin{array}{l}\text { Sulphur } \\
\text { Content }\end{array}$ & Index $=(B / A) \times S$ & $<0.6$ & $\begin{array}{l}0.6- \\
2.0\end{array}$ & $\begin{array}{l}2.0- \\
2.6\end{array}$ & $>2.6$ \\
\hline $\begin{array}{l}\text { Lawrence et al. } \\
2008\end{array}$ & $\begin{array}{l}\text { Shrinkage } \\
\text { Rate }\end{array}$ & Index $=\frac{R m}{L m} \times W t$ & \multicolumn{4}{|c|}{$\begin{array}{l}\text { No standard scale shown, but from the } \\
\text { report } \leq 55 \text { shows no slagging relative to } \\
\text { others }\end{array}$} \\
\hline $\begin{array}{l}\text { McLennan et } \\
\text { al. } 2000\end{array}$ & Fusibility & $A F=\frac{4 I D T+H T}{5}$ & $\begin{array}{l}> \\
1343^{\circ} \mathrm{C}\end{array}$ & $\begin{array}{l}1232- \\
1343^{\circ} \mathrm{C}\end{array}$ & $\begin{array}{l}1149- \\
1232^{\circ} \mathrm{C}\end{array}$ & $\begin{array}{l}< \\
1149^{\circ} \mathrm{C}\end{array}$ \\
\hline $\begin{array}{l}\text { McLennan et } \\
\text { al. } 2000\end{array}$ & $\begin{array}{l}\text { Percentage } \\
\text { of } \mathrm{Fe}_{2} \mathrm{O}_{3}\end{array}$ & Index $=\% \mathrm{Fe}_{2} \mathrm{O}_{3}$ in ash & $<6 \%$ & $6-7 \%$ & $>7 \%$ & - \\
\hline $\begin{array}{l}\text { Watt and } \\
\text { Fereday } 1969\end{array}$ & Viscosity & $\log (\mu)=\frac{m \times 10^{7}}{(T-150)^{2}}+c$ & \multicolumn{4}{|c|}{$\begin{array}{l}\text { High particle viscosity yields low } \\
\text { slagging potential }\end{array}$} \\
\hline Yin et al. 1998 & Fusibility & $\begin{array}{c}S T=a\left(\mathrm{SiO}_{2}\right)+b\left(\mathrm{Al}_{2} \mathrm{O}_{3}\right)+c\left(\mathrm{Fe}_{2} \mathrm{O}_{3}\right) \\
+f(x)+g\end{array}$ & $(\mathrm{CaO})$ & $(M g O)$ & $\begin{array}{l}\text { High fus } \\
\text { yields lo } \\
\text { slagging }\end{array}$ & oility \\
\hline
\end{tabular}

used to conduct calculation of empirical numerical slagging indices and the combustion performance studies using computational fluid dynamics at a later stage.

Slagging indices has been studied previously by other researchers to find the correlations to properly predict the collision behaviour of the ash. This was done by understanding its fusibility and viscosity of coal ash in the furnace and the ash particles. By having the information for the slag characteristics, the study can be further investigated by predicting the slag sticking probability. Since not all the coals are made up with the same mineral components, it is required to have user defined function to simulate the slag growth. It is important to understand how much energy does the slag droplet has in order to predict its mechanistic bouncing potential after impact [7].

Table 1 highlighted the existing numerical slagging indices correlation which used the proximate analysis of the coal ash in order to calculate the slagging indices proposed in the earlier studies. The fusibility also known as softening temperature proposed by the study of back propagation of neural networks from previous works that investigate the corresponding percentage of each minerals and oxides result towards the softening temperature alteration $[3,4]$. Watt and Fereday viscosity model utilized the neural network study by Yin [3] as the viscosity model incorporated the softening temperature calculation into the equation. Hence by calculating the constant for each minerals composition as the neural network, the composition has the ability to alter the temperature and viscosity [8]. The viscosity model of Watt and Fereday (1969) is as follows:

$$
\log (\mu)=\frac{m \times 10^{7}}{(T-150)^{2}}+c
$$

where, $\mathrm{m}$

$$
m=(0.00835) \mathrm{SiO}_{2}+(0.00601) \mathrm{Al}_{2} \mathrm{O}_{3}-0.109
$$

and $\mathrm{c}$,

$$
\begin{gathered}
c=(0.0415) \mathrm{SiO}_{2}+(0.0192) \mathrm{Al}_{2} \mathrm{O}_{3}+ \\
(0.0276) \text { Equiv. } \mathrm{Fe}_{2} \mathrm{O}_{3}+(0.016) \mathrm{CaO}-3.92
\end{gathered}
$$


Table 2 List of coals performance based on NSI

\begin{tabular}{llrll}
\hline Coal Type & Coal Brand & Shipment No & Coal Rank & Performance based on NSI \\
\hline A & Coal-A & 276 & Sub-bituminous & Best \\
A & & 404 & Sub-bituminous & Worst \\
B & Coal-B & 149 & Sub-bituminous & Best \\
B & & Sub-bituminous & Worst \\
B & Coal-C & 584 & Sub-bituminous & Best \\
B & & 345 & Sub-bituminous & Worst \\
B & Coal-D & 561 & Sub-bituminous & Best \\
B & & 165 & Sub-bituminous & Worst \\
F & 123 & Bituminous & Best \\
F & Coal-Y & 106 & Bituminous & Worst \\
Q & & 507 & Bituminous & Best \\
Q & Coal-Z & 77 & Bituminous & Worst \\
\hline
\end{tabular}

Softening temperature is calculated using the neural network which take into consideration the main monomers and modifying monomers as well as minerals like $\mathrm{CaO}$ and $\mathrm{MgO}[1,3]$.

where $\mathrm{Fe}_{2} \mathrm{O}_{3}$ (equivalent) is,

$$
100=\mathrm{SiO}_{2}+\mathrm{Al}_{2} \mathrm{O}_{3}+\mathrm{CaO}+\mathrm{MgO}+\text { Equiv. } \mathrm{Fe}_{2} \mathrm{O}_{3}
$$

In coal-fired power station, the coal received is based on shipment and it is known that the properties of these coals varies according to the shipment, despite coming from the same mines. Thus much uncertainty exists and in order to systematically categorized this coals, shipments that comes from similar coals mine are divided into two, namely good and bad coals. For the purpose of this investigation, 686 coal shipments were provided by the power station. The analysis was carried out and the list is narrowed down to smaller number using the numerical slagging indices. A total of 12 coals were selected based on its respective performance. The coals were divided into bituminous and sub-bituminous coal rank and were indicated in Table 2 as well as its status on performance. The coals were of 5 coal type namely A, B, F, Q and R with the 6 coal brands are the commonly used coals in the local coal power plant from various countries such as Indonesia, South Africa, Australia and etc.

\section{Results and discussion}

\subsection{Coal rankings}

Figure 1(a) and 1(b) show the graphical representation of the coals that have been segregated to be the best performing coals and the least performing coals. The best performing coals is indicated by the least tendency to slagging potential while the latter indicates the coals that has high tendency to slagging potential based on nominal benchmark highlighted in Table 1. Observation made with the successful coal has lower plotted benchmark value as shown in Figure 1(a) in comparison to Figure 1(b). Figure 1(a) shows higher value of AFT, Silica Oxide ratio, and viscosity, hence this yields smaller slagging potential. While the other parameters such as the basic to acid ratio, Iron (II) Oxide content, sulphur content increment yield higher slagging potential. The numerical slagging indices stated that normally for higher ash content and lower viscosity value, the slagging potential will increase as well [2]. 

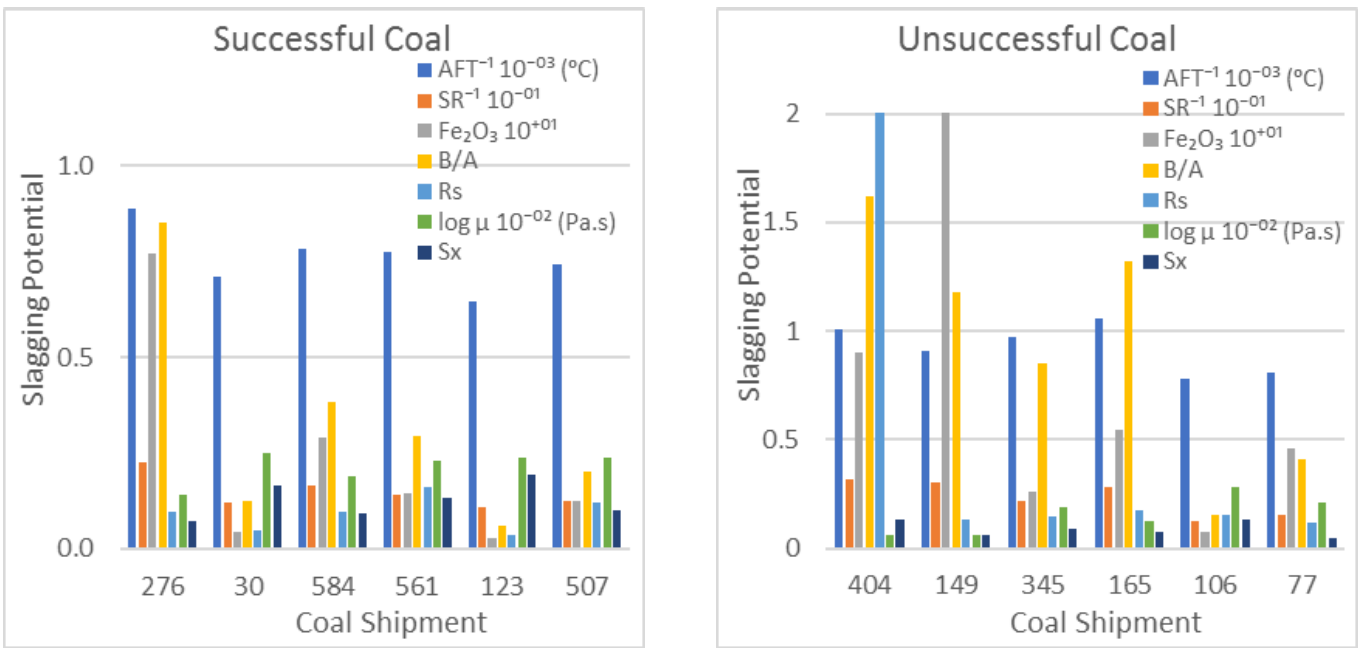

Figure 1 Comparison of slagging potential for different type of coal and shipment (a) Best performing coal (successful) and (b) Least performing coal (unsuccessful).

Figure 2 shows the comparison between the same coal brand of low slagging propensity and high slagging propensity. In this figure, the low slagging propensity coals is indicated on the left while the latter is on the right. The coals were arranged such that the best and worst performing coals of the same brand are placed side by side in order to observe the difference. Generally, high quality coals of low slagging propensity have low values for slagging indices while its counterpart of low quality coals recorded higher readings. The seven parameters are the existing indices to predict slagging propensity. The first eight coals are sub-bituminous coals with 30-Coal-B, 584-Coal-C and 561-Coal-D performed as good as the expensive bituminous coal however the overall properties of bituminous coals are better performing and the values barely exceeded 0.8 .

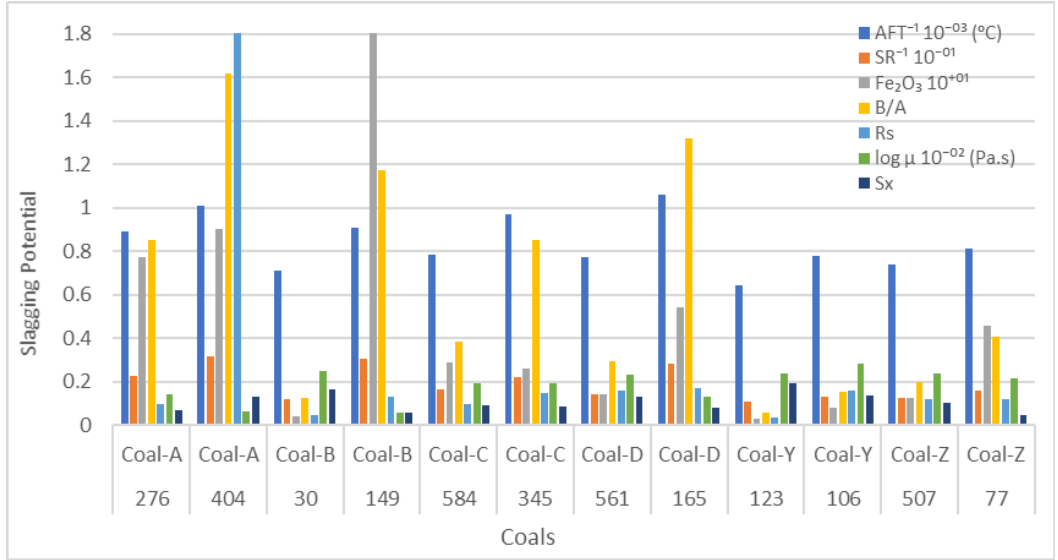

Figure 2. Comparison of the best performing coals and least performance coals of the same brand and rank. 


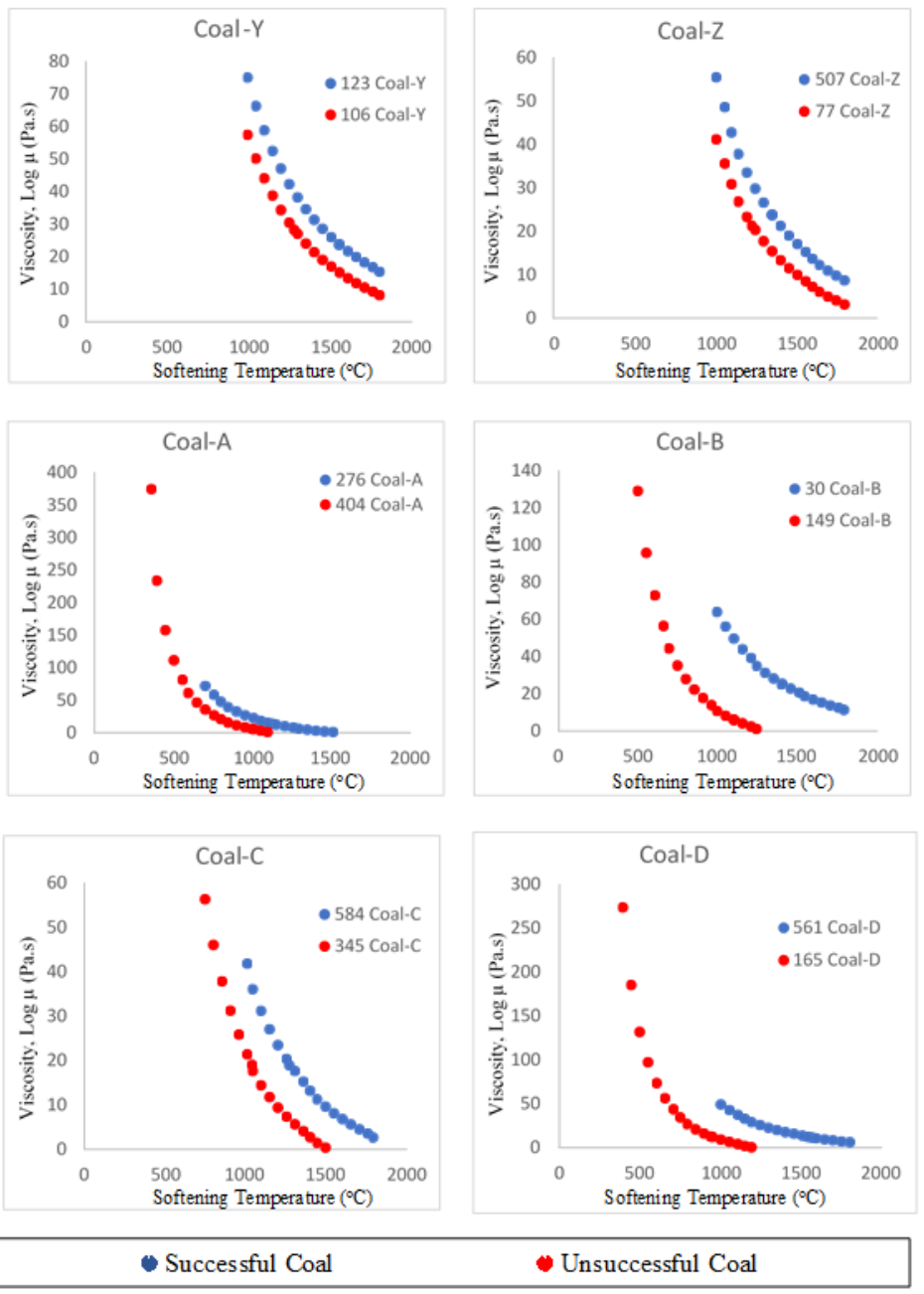

Figure 3 The comparison of viscosities and its relation to temperature for 6 different coal brands

Figure 3 shows the distribution of viscosity of the slag relationship with softening temperature. Higher softening temperature with high viscosity of slag showed low potential of slagging. Coal-A has high slagging potential as the temperature distribution at viscosity $50 \mathrm{~Pa} . \mathrm{s}$ is in the region of $650^{\circ} \mathrm{C}$ to $800^{\circ} \mathrm{C}$. Bituminous coals such as Coal-Y and Coal-Z have higher softening temperature with smaller viscosity such as $1300^{\circ} \mathrm{C}$ to $1500^{\circ} \mathrm{C}$ for Coal-Y and $1150^{\circ} \mathrm{C}$ to $1350^{\circ} \mathrm{C}$ for Coal-Z with $25 \mathrm{~Pa} . \mathrm{s}$ viscosity. However, high softening temperature are required to maintain the 15 to $25 \mathrm{~Pa}$.s viscosity to ensure slag is able to flow in the furnace else fluxing is required [9]. Coal-C performed fairly well as a sub-bituminous coal with the $950^{\circ} \mathrm{C}$ to $1250^{\circ} \mathrm{C}$ for $25 \mathrm{~Pa}$.s viscosity for both good performing and low performing coals.

\section{Conclusions}

Based on the investigation carried out on bituminous and sub-bituminous coals, the mineral composition of coal ash was subjected to slagging indices, sulphur content, B/A ratio, fusibility, silica oxide ratio, numerical slagging indices, softening temperature and viscosity at the corresponding temperature. Low softening temperature of coal indicates high slagging potential. The temperature can also be integrated into the Watt and Fereday viscosity model to predict coal slag potential. In order for 
the slag in the molten state not to accumulate, the nominal viscosity must be in the range of 15 to 25 Pa.s. The coal ash that is not susceptible to high temperature will have reduction in boiler heat transfer efficiency as the combustion has to be tuned to have acceptable temperature distribution. Softening temperature depends on the mineral composition of the coal ash at which an increase of Silica Oxide, $\mathrm{SiO}_{2}$ will increase the softening temperature and Iron (II) Oxide. This is also known to decrease the softening temperature as it alters the valence state of the mineral component. By understanding the slagging propensity, the coal utilization can be fine-tuned to produce enough temperature in order not to compromise the heat transfer efficiency of the furnace at the same time avoid the potential of slagging.

\section{Acknowledgments}

The authors would like to acknowledge the financial assistance received from the Ministry of Education Malaysia (MOE) under the Fundamental Research Grant Scheme (20150210FRGS).

\section{References}

1. M. U. Degereji, D. B. Ingham, L. Ma, M. Pourkashanian, A. Williams, Prediction of ash slagging propensity in a pulverized coal combustion furnace, Fuel, 101, 171-178 (2012).

2. M. U. Degereji, D. B. Ingham, L. Ma, M. Pourkashanian, A. Williams, Numerical assessment of coals/blends slagging potential in pulverized coal boilers, Fuel, 102, 345-353 (2012).

3. C. Yin, Z. Luo, M. Ni, \& K. Cen, Predicting coal ash fusion temperature with a backpropagation neutral network model, Fuel, 15, 1777-82 (1998).

4. A. Lawrence, R. Kumar, K. Nandakumar, K. Narayanan, A novel tool for assessing slagging propensity of coals in PF boiler, Fuel 87: 946-50 (2008).

5. J. D. Watt, F. Fereday, The flow properties of slag formed from the ashes of British coals: Part 1: Viscosity of homogenous liquid slag in relation to slag composition, Fuel, 42, 99-103 (1969).

6. A. R. McLennen, G. W. Bryant, C. W. Bailey, B. R. Stanmore, T. F. Wall. Index for iron based slagging for pulverized coal firing in oxidizing and reducing conditions, Fuel,14, 349-354 (2000).

7. S. Balakrishnan, R. Nagarajan, K. Karthick, Mechanistic modelling, numerical simulation and validation of slag-layer growth in a coal-fired boiler, Energy, 81, 462-470 (2015).

8. B. Liu, Q. He, Z. Jiang, R. Xu, B. Hu, Relationship between coal ash composition and ash fusion temperatures, Fuel, 105, 293-300 (2013).

9. P. Wang, M. Massoudi, Slag behaviour in gasifiers. Part I: Influence of coal properties and gasification conditions, Energies, 6, 784-806 (2013). 